\title{
ポーラスシリコン
}

\author{
越 田信義・小山英 樹 - 須 田良幸 \\ 東京農工大学工学部 恶184 東京都小金井市中町 \\ (1992 年 12 月 15 日受理)
}

\section{Porous Silicon}

Nobuyoshi Koshida, Hideki Koyama and Yoshiyuki Suda

Faculty of Technology, Tokyo University of Agriculture and Technology

Nakacho, Koganei, Tokyo 184

(Received December 15, 1992)

\begin{abstract}
$\mathrm{HF}$ 水溶液中で単結晶シリコンを陽極酸化処理したときに形成されるポーラスシリコン (PS) の可視発光 亿ついて，研究の現状を報告する。まず，PS の発光特性を基礎物性と関連させながら整理し，つぎに表面 電子構造と発光との密接な関係を裏づける最近の実験結果を紹介する。以上を総合して, PS の可視発光が 効率よく発現するためには，シリコンクリスタリットへのキャリア閉じ込めと表面パッシベーションが相補 的に作用し合うととが重要であるととを示す。
\end{abstract}

\section{1. まえがき}

単結晶シリコンを $\mathrm{HF}$ 水溶中で定電流陽極酸化する ととにより形成されるポーラスシリコン (PS) は, 孤立 または連結した無数のシリコンクリスタリット（内径： 2〜5 nm）功なる1。。このような微細系ではバルクの原 子数と表面の原子数が同じオーダーになる。そのため実 験的にあ理論的にあ取り扱いは困難になるが，その半 面, 通常のシリコンでばみられない特異な物性が出現す る可能性が出てくる。

PS の最す際立った性質はその光物性にある。特に最 近見出された可視発光性は, シリコンの材料学的・技術 的制約を破るむのとして強い関心を集めている。高効率 のフォトルミネセンス $(\mathrm{PL})^{2,3)}$ に続いて, すでに固体接 合による注入エレクトロルミネセンス $(\mathrm{EL})^{4)}$ あ確認さ れた。

PS の構造や一般的性質および発光特性の概要につい てはすでに報告したので ${ }^{-8)}$, 本稿では発光機構"を考え るうえで重要な事項を中心に, 最近の実験結果之研究の 現状を紹介する。

\section{2. これまでの実験の概要}

\section{1 試料の作成}

PS を作成する基板には非縮退単結晶シリコンウエハ を用い，20〜 $50 \% \mathrm{HF}$ 水溶液またはエチルアルコール で希釈した $50 \% \mathrm{HF}$ 水溶液中で定電流（電流密度： 10 200 mA/ $/ \mathrm{cm}^{2}$ ) の陽極酸化（時間：5～60 min）を行 う。基板の伝導タイプは $\mathrm{p}$ 形および $\mathrm{n}$ 形，比抵抗は 0.1

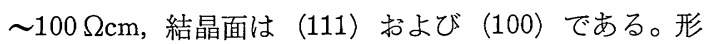
成される PS 層の厚さは 3 50 $\mu \mathrm{m}$ である。

$\mathrm{n}$ 形基板の場合には，PS の形成（シリコンの局所的 溶出）に心要なホールを供給するため, 陽極酸化のさい にタングステンランプによる光照射を行う。陽極酸化時 または陽極酸化後の光照射は, $\mathrm{p}$ 形基板において屯発光 強度を高めるのに有効であるととから ${ }^{3,10)}$ ，しばしば利 用される。

なお，PS そのものの物性を基板の影響なしに調べる うえで, 基板から永離したセルフサポーティング PS 膜 ${ }^{11}$ あ試料として重要である。

\section{2 主な実験項目}

PS にはナノメータ構造シリコン特有の性質が隠れて いる可能性があるため, その研究は総合的な見地から進 
める必要がある。われわれは光物性に重点をおき，以下 の点について実験的検討を進めてきた。

(a) 光電特性

。光導電効果: [半透明 $\mathrm{Au}$ 薄膜/PS 層/ $\mathrm{p}$ 形 $\mathrm{Si}$ 基 板 $/ \mathrm{Al}$ 薄膜] の構造をむつ光電セルの光電流-電 圧特性, 暗電流・光電流の温度依存性, 分光感度 およびその温度依存性 ${ }^{12)}$ 。

○光電気化学特性: 電解質溶液-PS 界面の光電変換 特性 ${ }^{13,14)}$ およびその電気的キャラクタリゼーショ ン $^{15,16)}$ 。

(b) 発光特性

○PL 特性: 発光スペクトルおよび発光強度の陽極酸 化条件依存性，温度依存性，陽極酸化時の光照射 効果など3,10,17,18)。

$\circ \mathrm{EL}$ 特性: 光導電セルと同じ構造の固体セルによる LED 動作特性, 発光スペクトルなど4,10,19)。

(c) 光学的特性

○PS 膜の光透過・吸収スペクトル（可視〜近紫 外) ${ }^{111}$ 。

○シンクロトロン放射光 (SOR 光) と分光エリプソ メトリーによる反射スペクトルのクラマース・ク ローニヒ解析と光学定数の決定 ${ }^{18)}$ 。

（d）電気的性質

PS 膜の比抵抗とその温度依存性 ${ }^{18)}$ 。

(e) 構造解析

。PS 膜のX 線回折 $^{20)}$, STM, ラマン散乱分光など。

（f）表面電子構造の解析

$\circ \mathrm{SOR}$ 光による光電子分光測定 ${ }^{21)}$ : 電子構造と $\mathrm{PL}$

発光特性との相関の究明

○電子スピン共鳴 (ESR) の測定 ${ }^{22)}$ : 電子状態の解析

と非発光再結合中心のアサインメント

上記項目のうち，いくつかの点については総説でも内

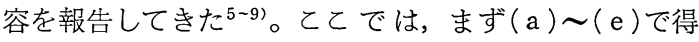
られた知見の中から，発光機構と関連する重要事項を他 の報告む含めてまとめ,つぎに（f ）に関する最近の検討 結果について述べる。

\section{PS の物性と発光}

前節 $(a) 〜(e) の$ 諸特性において, 発光機構と潹く結 びついていると思われる事項を以下に列挙しよう。

(i ) PS は可視領域に明確な光電感度を示す ${ }^{12 ~ 14) 。 ~}$

(ii) PS の残留シリコンは電気的に空乏状態にあ $3^{15,16)}$ 。

（iii） PL スペクトルは PS の多孔度が大きいほどブ ルーシフトする傾向を示すが10,11), 表面の酸化 (パッシベーション) あその重要な因子である。 (iv) 特に, PS を RTO 法 (Rapid Thermal Oxidation）などにより高温 $\left(800 \sim 1000^{\circ} \mathrm{C}\right)$ で熱酸化す るととは，PL のブルーシフトだけでなく，発光 の高効率化と安定化にあ非常に有効である ${ }^{23 ~ 25) 。 ~}$

（v）EL は発光領域全体にわたって均一であり，EL 強度の電圧依存性および EL 強度-電流特性から, 発光は強電界効果に基づくものではなく，PS のキャリア注入によるものとみられる ${ }^{4,10)}$ 。

（vi） 固体 EL セルでは発光効率がまだ低く（10-2 $\left.10^{-3} \%\right)^{4,26)}$ ，動作寿命も短いが，理想的な接合形 態とみられる電解質溶液-PS セルでは，発光効率 が $0.1 \%$ 以上の安定な発光が得られている27)。

（vii） PS は結晶シリコンの光学的特性を基本的には保 持しているが，吸収端や直接遷移に対応する吸収 ピークには $0.3 \mathrm{eV}$ 程度のブルーシフトが認めら れ，シリコンクリスタリットにおいてバンド構造 変化が生じているととが予想される ${ }^{18)} 。$

（viii）少なくとも PS の光学的性質はアモルファスシリ コンとはまったく異なる ${ }^{18)}$ 。

（ix） PS の室温での比抵抗は基板より数けた高く，低 温ではホッピング形，室温付近では熱活性形の伝 導モードを示す ${ }^{12,18)}$ 。

（x） PS の PL 発光強度は約 $200 \mathrm{~K}$ で最大になり，そ れより高温・低温の両側では減少する ${ }^{18,28)}$ 。

（xi） PL 強度が最大になる温度は PS の電気伝導モー ドがホッピング形から熱活性形に変化する温度に 対応するととから，高温側での発光強度減少は熱 的クエンチによるものといえる。低温側での発光 強度低下の原因は, 光励起キャリアのトンネル散

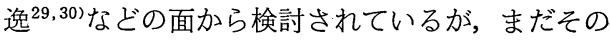
詳細は明らかになっていない。

（xii） 発光を顕著に示す PS は整然とした 1 次元的な量 子細線アレイからなるのではなく，無数のシリコ ンクリスタリットを含んだスポンジ状シリコン骨 格からなるととがわかってきた ${ }^{1,13)}$ 。格子歪が存 在するものの，基板の単結晶性は保持しており， このととは上記 (vii)，（viii)とも符号する。

以上のととを総合すると，PS の発光特性の概要はか なり整理されつつあり, 発光機構の解明をめぐる研究 は，PS のミクロな物性を本格的に検討すべき段階に 入ったといえよう。

特にシリコンクリスタリットのバルクの物性と切り離 すととのできない表面電子構造の解析は，発光過程を明 らかにするために不可欠の課題である。そこで，次章で はその一環として行った研究の概要を述べる。 


\section{PS の表面電子構造と発光}

\section{1 光電子分光による解析 ${ }^{211}$}

PL 発光強度が大きく異なる三つの PS 試料につい て, SOR 光による光電子分光の測定と解析を行った。 実験に用いた PS は，いずれす p 形 (100) Si ウエハー $(2 \sim 6 \Omega \mathrm{cm})$ 上に作成したもので，陽極酸化の電流密度 之時間などが以下のように異なる。

a. $10 \mathrm{~mA} / \mathrm{cm}^{2}, 5 \mathrm{~min}$, 光照射なし。

b. $200 \mathrm{~mA} / \mathrm{cm}^{2}, 15 \mathrm{~s}$, 光照射なし。

c. $10 \mathrm{~mA} / \mathrm{cm}^{2}, 5 \mathrm{~min}$, 陽極酸化後に $500 \mathrm{~W}$ タング ステンランプで $15 \mathrm{~min}$ 光照射。

これらの試料は，作成後直ちにエチルアルコール中に 保存し, 空気にさらすととなく真空チャンバ内にセット した。

光電子分光の測定は，光源を $S O R$ 光として（東大物 性研 $0.4 \mathrm{GeV}$ 電子蓄積リング), $8 \times 10^{-11}$ Torr 以下の 真空度で行った。測定項目は価電子帯スペクトルと Si $2 \mathrm{p}$ スペクトルである。

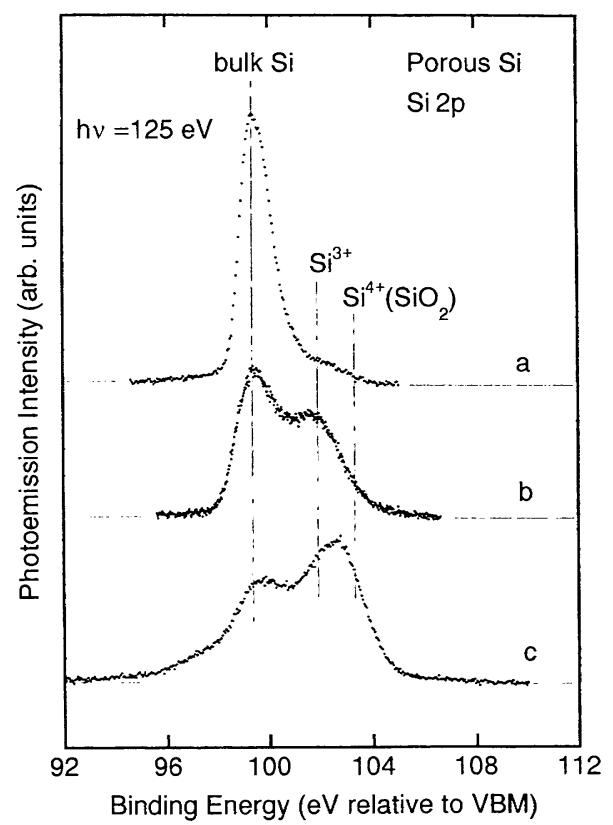

図 13 種類の PS 試料の $\mathrm{Si} 2 \mathrm{p}$ 光電子スペクト $ル^{211}$

基板は $\mathrm{p}$ 形 $(100) \mathrm{Si}$ ウエハ $(2 \sim 6 \Omega \mathrm{cm}) ， 50 \%$ $\mathrm{HF}:$ エタノール =1: 1 の溶液中で陽極酸化を 行った。各試料の陽極酸化電流密度, 時間, 光照 射条件はつぎのとおり

a : $10 \mathrm{~mA} / \mathrm{cm}^{2}, 5 \mathrm{~min}$, 光照射なし

b : $200 \mathrm{~mA} / \mathrm{cm}^{2}, 15 \mathrm{~s}$, 光照射なし

c : $10 \mathrm{~mA} / \mathrm{cm}^{2}, 5 \mathrm{~min}$, 陽極酸化後 $500 \mathrm{~W}$ の $\mathrm{W}$ ランプで $15 \mathrm{~min}$ 光照射
光電子分光と合わせて，各試料の PL スペクトルむ $\mathrm{He}-\mathrm{Cd}$ レーザー光（波長 $325 \mathrm{~nm}$ ) を励起源として測定 した。

図1は，三つの試料 a，b，cの Si $2 \mathrm{p}$ スペクトルを 比較して示したものである。低電流密度で陽極酸化した 試料 a では, $\mathrm{Si}_{2} \mathrm{O}_{3}$ による小さなショルダーがみられる が，主要なピークはバルク Si の信号からなっている。 酸化によるピークの相対強度は，高電流密度で陽極酸化 した試料 $\mathrm{b}$ で増大しているのか認められる。さらに，光

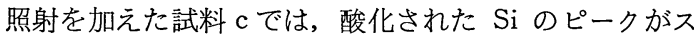
ペクトルの主要な成分となる。

試料 c のスペクトルのメインピーク間のエネルギー差 は約 $3.5 \mathrm{eV}$ であることから，ての試料の一部は完全に 酸化されていると考えられる。このように，酸化の程度 は試料 a , b , c の順序で高くなっている。

このような電子状態の違いは PL 効率と密接に関係し ていることが，PL 測定から判明した。すなわち，三つ の試料のうち，a の PL 強度は測定が困難なほど微弱で あるのに対し，b，c と酸化が進むにしたがって PL 強 度は著しく高まっていく。

試料 b，c のPL スペクトルを図 2 亿示す。最む酸化 の程度の高い試料 $\mathrm{c}$ の PL 強度は $\mathrm{b}$ に比べて約 2 けたも 高い。陽極酸化後の光照射は光誘起酸化を通じて PL 効 率の向上をむたらしているととが図 1 と図 2 の結果から 明らかになった。陽極酸化時の光照射も同様の効果を屯 っているととが予想される。

酸化による PL 強度の増大は, 表面のパッシベーショ ンとバンドベンディングの二つに起因していると考えら れる。前者は非発光再結合の抑制に，後者は光励起キャ リアの効率的閉じ込めに，それぞれ寄与しているである う。

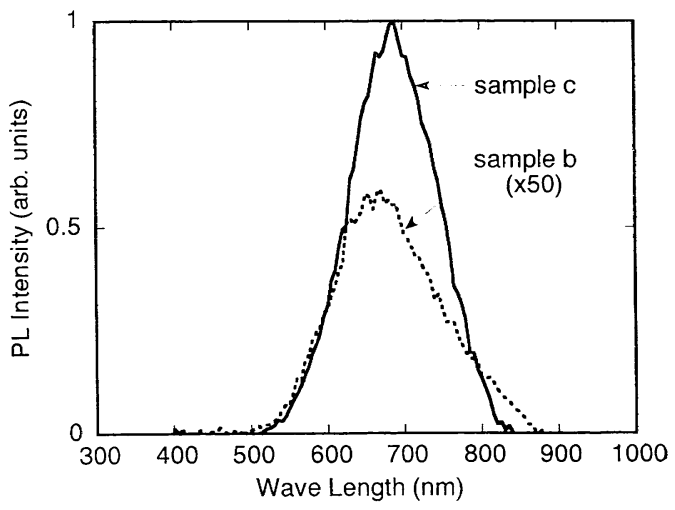

図 2 二つの PS 試料の PL スペクトル21) 試料 b, c は図1の b, c 飞対応。励起源には 10 $\mathrm{mW} \mathrm{He}-\mathrm{Cd}$ レーザー（波長 $325 \mathrm{~nm}$ ) を使用 
電子一正孔対が閉じ込められたとしても，非発光緩和 を助長する欠陥が界面に存在すれば, 効率的な PL は生 じない。表面が活性な PS ではなおさらこの問題はきび しいであろう。こてで, 表面のパッシベーションが PL の効率の決定要因としてクローズアップされてくる。

次節では, 非発光再結合の原因となる界面の欠陥が何 飞起因しているのかを ESR の測定結果によって説明す る。

\subsection{ESR 測定による解析 ${ }^{22}$}

$\mathrm{p}$ 形非縮退基板上に標準的な陽極酸化を施した後, 電 気化学的に剶離した PS 膜について, 室温で ESR 信号 を測定した。基板には，(111）面と（100）面の 2 種類の

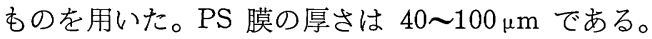

図 3(a )，(b ) は，(111）基板之（100）基板加弓作成 した PS 膜の ESR 信号を示したものである。磁界 $B$ に 対する角度の関係が同等の条件で比較するため, 同図 （a）には試料面の法線と $B$ の方向とのなす角度が $55^{\circ}$, 同図”b ) には試料面に $B$ が垂直な場合の結果が示され ている。

との結果からまず指摘できるのは,「PS は膨大な比表 面積 $\left(200 \sim 600 \mathrm{~m}^{2} / \mathrm{cm}^{3}\right)$ を有するにあかかわらず，その ESR 信号は強くない」というととである。乙れには，陽 極酸化時に残留シリコン表面のダングリングボンドが水 素終端されるととが効いていると思われる。

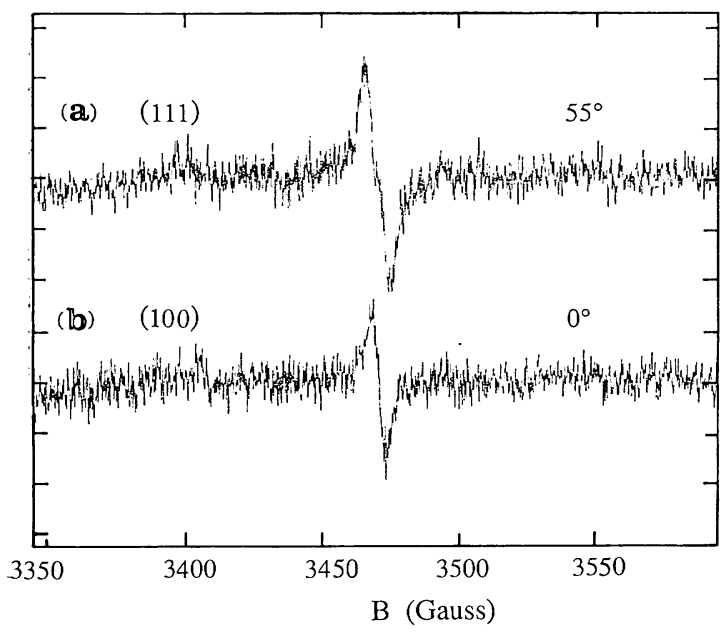

図 3 二つのセルフサポーティング PS 膜の ESR スペクトル 各試料の基板は以下のとおり

(a ) : p 形, (111), $0.2 \sim 0.4 \Omega \mathrm{cm}$

(b ) : p 形, (100), 2 6 $\Omega \mathrm{cm}$

陽極酸化条件はともに同じ (50\% HF, $10 \mathrm{~mA}$ / $\left.\mathrm{cm}^{2}, 60 \mathrm{~min}\right)$ 。図中の角度は, 試料面の法線と 磁界とのなす角度を表わす
ESR の信号は弱いとはいえ，その強度は PL 効率と 密接に結びついている。たとえば，図 3(a)，（b ）の試 料の PL スペクトルを測定したととろ，図4のような結 果が得られた。ESR 信号が比較的強い試料では PL 強 度が著しく低下するのがわかる。基板の結晶面でてのよ うな違いが生ずる原因は, 陽極酸化のさいの空隙の発達 に優先方向があるととと関係した構造上の原因む考えら れるが，その検証にはより定量的な解析が必要である。

ESR 信号の角度依存性をさらに検討するため，(100) 基板から作成した PS 膜について詳細な測定を行った。 二つの典型的な角度に対する ESR スペクトルを図 5 に 示す。 $\boldsymbol{B} \|[100]$ のさには 1 本のラインが, $\boldsymbol{B} \|[111]$ のときには強度比 $1: 3$ の 2 本のラインが観測されて いる。

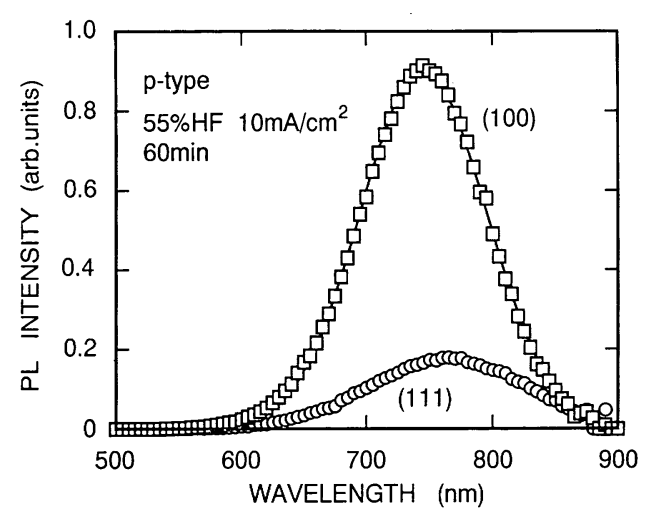

図 4 セルフサポーティング PS 膜の PL スペクト ル。試料 ( a ), (b)は図 3 のあの亡同じ

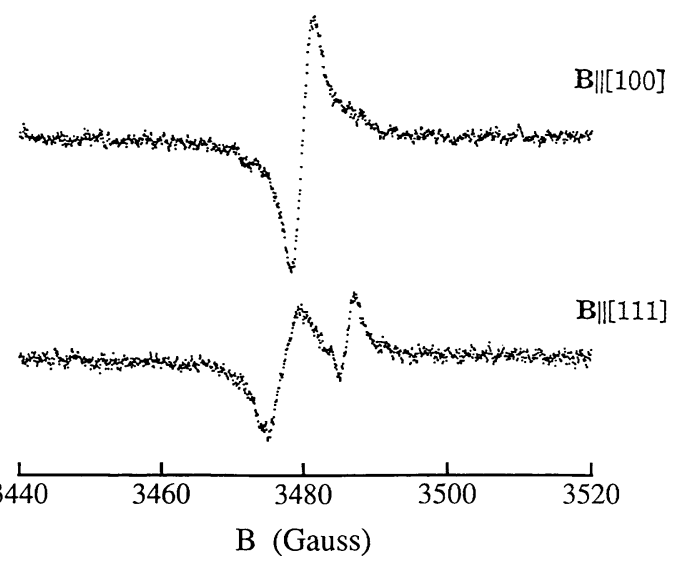

図 5 セルフサポーティング PS 膜の ESR スペク トルの角度依存性

基板 : $\mathrm{p}$ 形， $(100) ， 2 \sim 6 \Omega \mathrm{cm}$

陽極酸化条件 : $50 \% \mathrm{HF}+$ エタノール (1:1), $10 \mathrm{~mA} / \mathrm{cm}^{2}, 180 \mathrm{~min}$ 
他の角度における信号む含めて解析した結果,

（i） ESR スペクトルは $\mathrm{C}_{3 V}$ 対称性をもつ常磁性中心 として解析可能,

（ii） $\mathrm{g}$ の主值から，乙の常磁性中心は $\mathrm{Si}-\mathrm{SiO}_{2}$ 界面に できる $\mathrm{P}_{\mathrm{b}}$ 中心と同形のダングリングボンドに基 づくとみなせる，

の 2 点が明らかになった。

これらの知見は，ダングリングボンドの周囲がシリコ ンの結晶構造を保持していることを微視的に実証すると とあに，発光機構の考察に大きな示唆を与える。また， 前節の光電子分光の結果とむ合わせ，発光の高効率化と 安定化の指針を見出すうえであ有用な情報をあたらして いる。

なお, 図 3(a), (b) あ含め, 通常の方法で作成した as-anodized の PS では, スピン密度は $10^{16} \sim 10^{17} \mathrm{~cm}^{-3}$ である。種々の試料の測定により, ESR 信号と発光効 率の関係が今後定量的に明らかになるであろう。

\section{5.むすび}

PS の可視発光現象には, シリコンクリスタリットバ ルクのバンド構造変化だけでなく, 表面の電子構造む深 く関与していることを示した。PS の可視発光がシリコ ンクリスタリット内部の量子サイズ効果によるとして あ，それは表面のパッシベーションによって支えられて いる。シリコンナノ構造ではバルクと表面は分離でき ず，発光過程においてそれらは互いに相補的な役割を果 たしていると考えるべきであろう。その意味で，PS の 発光は技術的なインパクトをもつとともに，固体表面科 学にあ新たな問題を提起しているように思われる。

$\mathrm{SOR}$ 光電子分光の実験は東大物性研, 辛埴助教授に, ESR の解析は無機材研, 内田吉茂主任研究官にそれぞ れご助力をいただいた。実験にご協力をいただいた学生 諸氏とともに，とこに深く謝意を表する。

本研究の一部は，放送文化基金および文部省科研費一 般研究 (B)の補助により行われた。

\section{文献}

1) A. G. Cullis and L. T. Canham : Nature 353, 335 (1991).

2) L. T. Canham: Appl. Phys. Lett. 57, 1046 (1990).

3) N. Koshida and H. Koyama: Jpn. J. Appl. Phys. 30, L 1221 (1991).

4) N. Koshida and H. Koyama : Appl. Phys. Lett. 60, 347 (1992).

5）越田信義：固体物理 27, 152 (1992).
6) N. Koshida and H. Koyama : Optoelectronics 7, 103 (1992).

7) 越田信義, 小山英樹 : 応用物理 61, 805 (1992).

8）小山英樹, 越田信義: 表面科学 13, 402 (1992).

9）越田信義, 小山英樹 : 応用物理 61, 1269 (1992).

10) N. Koshida and H. Koyama : Nanotechnology 1 (1992) (in print).

11) H. Koyama, M. Araki, Y. Yamamoto and N. Koshida: Jpn. J. Appl. Phys. 30, 3606 (1991).

12) N. Koshida, Y. Kiuchi and S. Yoshimura : Proc. 10th Symp. Photoelectronic Image Devices, London, 1991 (IOP, Bristol, 1992) pp. 377-384.

13) N. Koshida, H. Koyama and Y. Kiuchi : Jpn. J. Appl. Phys. 25, 1069 (1986).

14) N. Koshida, M. Nagasu, K. Echizenya and Y. Kiuchi : J. Electrochem. Soc. 133, 2283 (1986).

15) H. Koyama and N. Koshida: J. Electrochem. Soc. 138, 254 (1991).

16) N. Koshida and K. Echizenya : J. Electrochem. Soc. 138, 837 (1991).

17）小山英樹, 越田信義：光学 21，698 (1992).

18) N. Koshida and H. Koyama : MRS Symp. Proc. 283 (1993) (in print).

19) N. Koshida and H. Koyama: MRS Symp. Proc. 256, 219 (1992).

20) H. Koyama and N. Koshida : Ext. Abst. Int. Conf. SSDM, Yokohama, 1991 (Business Center for Acad. Soc. Jpn., Tokyo, 1991) p. 314.

21) Y. Suda, T. Ban, T. Koizumi, M. Minagawa, H. Koyama, N. Koshida, Y. Tezuka and S. Shin : to be published.

22) Y. Uchida, H. Koyama and N. Koshida : to be published.

23) T. Ito, T. Ohta and A. Hiraki : Jpn. J. Appl. Phys. 31, L 1 (1992).

24) A. Nakajima, T. Itakura, S. Watanebe and N. Nakayama: Appl. Phys. Lett. 61, 46 (1992).

25) V. Petrova-Koch, T. Muschik, A. Kux, B. K. Meyer, F. Koch and V. Lehmann : Appl. Phys. Lett. 61, 943 (1992).

26) F. Kozlowski, P. Steiner, H. Sandmaier and W. Lang: MRS Symp. Proc. 283 (1993) (in print).

27) M. I. J. Beale, L. T. Canham and T. I. Cox: MRS Symp. Proc. 283 (1993) (in print).

28) X. L. Zheng, W. Wang and H.C. Chen : Appl. Phys. Lett. 60, 986 (1992).

29) J. C. Vial, A. Bsiesy, F. Gaspard, R. Herino, M. Ligeon, F. Muller, R. Romestain and R. M. Macfarlane: Phys. Rev. B 45, 14171 (1992).

30) S. Billat, A. Bsiesy, F. Gaspard, R. Herino, M. Ligeon, I. Mihalcescu, F. Muller, R. Romestain and J.C. Vial: MRS Symp. Proc. 283 (1993) (in print).

31) K. Nakagawa, A. Nishida and T. Shimada : MRS Symp. Proc. 283 (1993) (in print). 